\title{
ステンレスチューブを母材とする銀中空ファイバの可視光伝送特性の改善
}

\author{
岩井克全 ${ }^{1}$, 高久 裕之 ${ }^{1}$, 宮城光信 ${ }^{1}$, 石 芸尉 ${ }^{2}$ \\ 1仙台高等専門学校 ( $=989-3128$ 宮城県仙台市青葉区愛子中央四丁目16-1) \\ 2復旦大学 (上海市邯鄲路220号, 200433)
}

\section{Improvement of Transmission Properties of Visible Light for Ag Hollow Fiber Based on Stainless Tube}

\author{
Katsumasa IWAI ${ }^{1}$, Hiroyuki TAKAKU ${ }^{1}$, Mitsunobu MIYAGI ${ }^{1}$, and Yi-Wei SHI ${ }^{2}$ \\ ${ }^{1}$ National Institute of Tech., Sendai College, 4-16-1 Ayashicyuo, Aoba-ku, Sendai 989-3128, Japan \\ ${ }^{2}$ Fudan University 220 Handan road, Shanghai 200433, China
}

(Received July 27, 2016)

\begin{abstract}
For medical application by using the infrared laser, it is necessary to keeps high mechanical strength of the hollow fibers. We chose a stainless tube as the base material for the hollow fibers. In order to reduce roughness of inner surface of stainless tube which causes the additional transmission loss. We proposed a new material to fabricate a low-loss-silver-hollow fiber based on a stainless tube. The new material is an acrylic-silicon resin material which is used as a buffer polymer to the inner walls of stainless tubes for a low-loss characteristic. We also discuss the transmission properties of visible pilot beam and Er: YAG laser light in the silver-hollow fibers. The loss for the 550- $\mu \mathrm{m}$-bore size, 1-m-length silver-hollow fiber was $5.9 \mathrm{~dB}$ under straight configuration, and $8.8 \mathrm{~dB}$ under the configuration of a 180 degree bending with a $20.25-\mathrm{mm}$ bending radius at the wavelength of $650 \mathrm{~nm}$.
\end{abstract}

Key Words: Hollow fiber, Laser diode, Stainless tube

1. はじめに

可視〜赤外波長帯レーザー用としてフレキシブルに伝 送可能な伝送路の一つとして, 中空ファイバがある ${ }^{1-4)}$. 中空ファイバでは, 空気のコアとクラッディング境界で 光は全反射しないため, レーザー光は損失を伴って伝搬 している，よって，中空ファイバ内面の反射率を高くす れば，低損失な伝送路が実現可能である，実用的な中空 ファイバとして, ガラスパイプ内面に銀層とポリマー層 を形成したポリマー内装銀中空ファイバがあり5)，この 中空ファイバは, 赤外光と同時に可視光も伝送できると いう特徴がある6). しかし，母材にガラスパイプを用い た中空ファイバは, ガラスパイプ内面に銀薄膜を形成す る際に使用する銀鏡反応の溶液が, 石英ガラス表面の微 小欠陥生成を助長するため, 曲げ強度が弱くなることが 報告されている7-10)。 そのため, 母材として曲げても破 断しないステンレスチューブを用いた中空ステンレス ファイバの研究が行われてきた ${ }^{11)}$ 。これまで液相法によ り，環状オレフィンポリマー(COP) を内面平滑化膜とし て内装することで内面粗さを大幅に低減した中空ステン レスファイバ(内径 $1.1 \mathrm{~mm}$, 長さ $13 \mathrm{~cm}$ )が実現されてい る ${ }^{12)}$. しかし, COPと金属膜の付着力は弱く, また製作 したファイバは短尺であり，改善の余地があった。そこ で本研究では, ステンレスチューブの内面平滑化に適し
た新しい材料を選択し，その効果を実証する.

2. 内面平滑化膜の選択と銀中空ステンレス 短尺ファイバの試作

Fig. 1に, 銀中空ステンレスファイバの構造を示す. 市販されているステンレスチューブの内面粗さは， 0.3 $0.9 \mu \mathrm{m}$ と低減してきているが，まだ散乱損失は大きく,

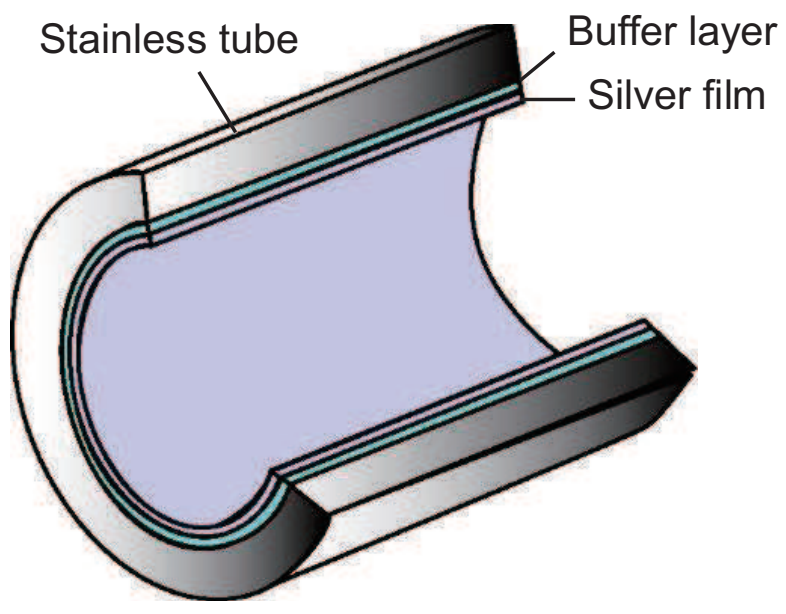

Fig. $1 \mathrm{Ag} / \mathrm{Buffer} / \mathrm{SUS}$ hollow fiber. 
伝送効率は低い。そこで銀膜を成膜する前に，内面粗さ の低減を図る。銀中空ステンレスファイバを製作する上 では，内面平滑化膜の作用を持つポリマーを最初に，又 テンレスチューブ $(\mathrm{SUS})$ に内装し，その後に銀鏡反応に よって銀膜 $(\mathrm{Ag})$ を，成膜する必要がある。この際，ス テンレスチューブと内面平滑化膜としてのポリマー, ポ リマー上に成膜される銀膜の接着性が重要な課題となる。

低損失な銀中空ステンレスファイバを実現できれば, その次に, 従来より採用されていた送液法によって低損 失化用のポリマー (COP) を所定の厚さを持って成膜する ことで, $\mathrm{CO}_{2}$ レーザー, Er:YAGレーザーなどの赤外レー ザー光用の低損失な伝送路を実現できる ${ }^{12)}$.

\section{1 内面平滑化膜の選択}

内面粗さをカバーできる内装平滑化膜に要求される条 件としては,

（1）厚い膜を成膜できる，または重ね塗りができること.

(2) ステンレスチューブと銀膜との付着力が強い.

(3) 送液, 乾燥によって一様な膜を成膜可能であること. が必要である。上記の条件を満たす内面平滑化用ポリ マー膜材料を種々検討した結果, シリコンアクリル樹脂 が一つの候補であることが分った。このシリコンアクリ ル樹脂は，金属板へ銀メッキする際の下地材であり，金 属膜との付着力に優れたポリマーである。

\section{2 銀中空ステンレス短尺ファイバの試作} シリコンアクリル樹脂膜の形成は送液法により行う。 まず, 内径700 $\mu \mathrm{m}$ 銀中空ファイバに送液速度 $4 \mathrm{~cm} / \mathrm{min}$ シリコンアクリル樹脂溶液の送液を行った。 上記の手法 により，濃度 $23.8 \mathrm{wt} \%$ のシリコンアクリル樹脂溶液で製 作したシリコンアクリル樹脂膜内装銀中空ファイバ（内 径700 $\mu \mathrm{m}$, 長さ30 cm) の可視波長域における損失波長 特性をFig. 2に示す. Fig. 2のピークは干渉によるもので

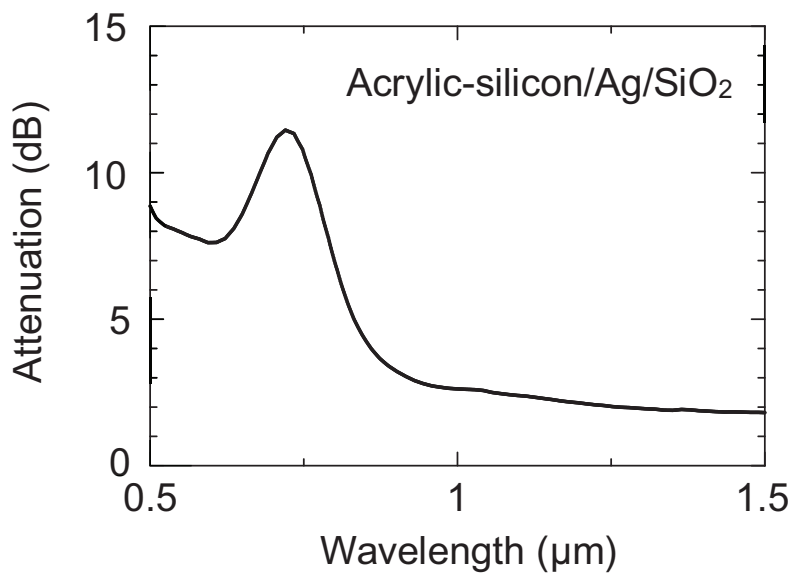

Fig. 2 Measured loss spectra of Acrylic-silicon/Ag/ $\mathrm{SiO}_{2}$ hollow fibers $(700 \mu \mathrm{m} \phi \times 30 \mathrm{~cm})$ fabricated by using Acrylic-silicon solution with a concentration of $23.8 \mathrm{wt} \%$, where the thickness of Acrylic-silicon resin film is $0.16 \mu \mathrm{m}$. The fibers are excited by the Gaussian beam with a full-width at half-maximum of $10.6^{\circ}$.
ある.ピークとなる波長から幾何光学的手法により， シ リコンアクリル樹脂膜の膜厚を推定でき, この場合は, $0.16 \mu \mathrm{m}$ である。この手法を用いて，溶液濃度を変えた場 合のシリコンアクリル樹脂膜厚の推定を行った. Fig. 3 に，シリコンアクリル樹脂膜の溶液濃度に対する膜厚特 性を示す。Fig. 3によれば, 約 $45.5 \mathrm{wt} \%$ の溶液を用いれ ば, 1 回の成膜で約 $0.5 \mu \mathrm{m}$ の膜厚を成膜でき, 内面平滑 化の効果が期待できる.

内径 $550 \mu \mathrm{m}$, 外径 $780 \mu \mathrm{m}$, 長さ $20 \mathrm{~cm}$ のステンレス チューブにシリコンアクリル樹脂溶液を送液し，その 後, 窒素ガスを流量 $50 \mathrm{ml} / \mathrm{min} ゙$ 流しながら, 室温乾燥 を60分間行った。送液速度は，約 $8 \mathrm{~cm} / \mathrm{min}$ である。その 後, $\mathrm{SnCl}_{2}$ 溶液による前処理を用いた銀鏡反応により銀 膜形成を行った. Fig. 4に, 銀中空ステンレス短尺ファ イバ(内径 $550 \mu \mathrm{m}$, 外径780 $\mu \mathrm{m}$, 長さ $20 \mathrm{~cm}$ )の波長損失 特性（FWHM10.6のガウスビームで励振）を示す。これ

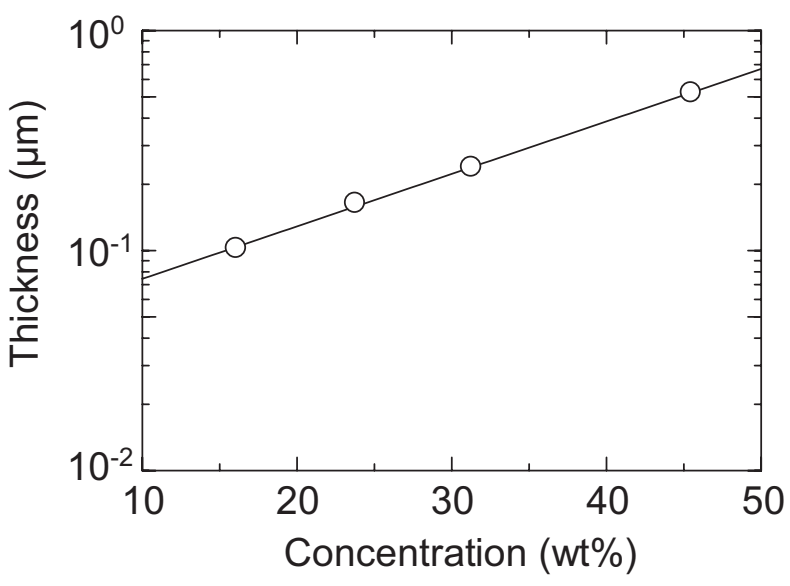

Fig. 3 Relationship between concentration of Acrylic-silicone solution and deposited Acrylic-silicone film thickness with a constant coating speed of $4 \mathrm{~cm} /$ min for $700-\mu \mathrm{m}$-bore fiber.

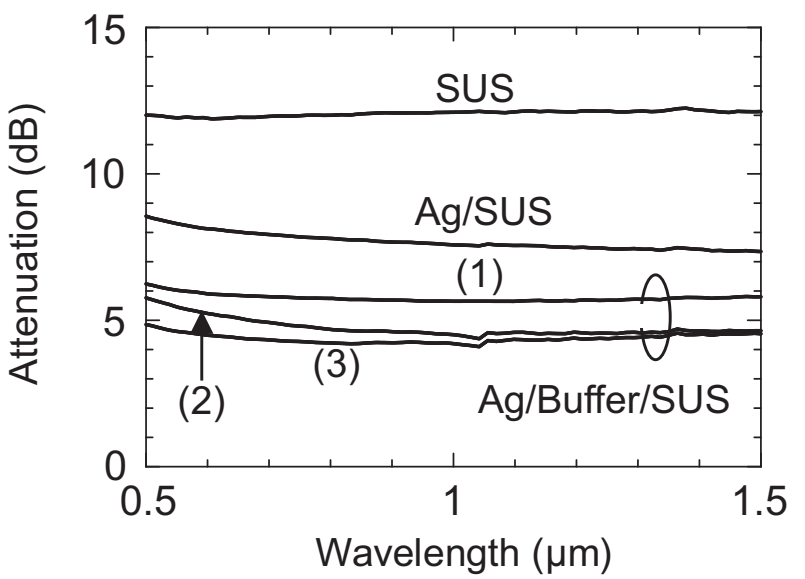

Fig. 4 Measured loss spectra of Ag/Buffer/SUS hollow fibers $(550 \mu \mathrm{m} \phi \times 20 \mathrm{~cm})$ fabricated by using Acrylic-silicon solution with various coating times, where the coating times of Buffer film is 1 time (1), 3 times (2), and 4 times (3), respectively. The fibers are excited by the Gaussian beam with a full-width at half-maximum of $10.6^{\circ}$. 
によれば，ステンレスチューブに銀膜を成膜することに より, 低損失となり, 更に, 内面平滑化膜としてシリコ ンアクリル樹脂膜を成膜した銀中空ステンレス短尺ファ イバは低損失となった。内装平滑化膜を4回重敉塗りす ることで，伝送特性は低損失化していくことが分る。 5 回の重ね塗りも試みたが, 膜の不均一性が増加し, Ag 膜を一様に成膜することが困難であり，特性は劣化し た。以上の伝送特性をまとめると内面平滑化膜としての シリコンアクリル樹脂の重ね塗り回数は4回が適当と結 論される.

銀鏡反応の前処理として, 従来法 ${ }^{1)}$ は, 母材となるス テンレスチューブの内に $\mathrm{SnCl}_{2}$ 溶液を流すことで前処理 は完了する。その後, 銀鏡反応を行う. $\mathrm{SnCl}_{2}$ 溶液を流 すことで，付着面が活性化され，銀の成膜速度が向上す る. 本手法では, $\mathrm{SnCl}_{2}$ 前処理の前に, コンディショニ ング処理を導入する。コンディショニング処理は, 母材 表面の $\mathrm{SnCl}_{2}$ を $\mathrm{Sn}^{2+}$ の陽イオンにすることで触媒の吸着を 高め, めっきムラを低減する効果がある。コンディショ ニング処理は, コンディショナー(表面調整歳)溶液をス テンレスチューブ内に流すことで完了する. その後, 水 洗いを3分行い, センシタイザー処理 $\left(\mathrm{SnCl}_{2}\right.$ 処理 $)$ を行 い，更に，水洗いを3分行い，その後，従来と同様に銀 鏡反応を行う. Fig. 5にコンディショニング処理の効果 について，処理の有無の比較を短尺ファイバの試作で 行った結果を示す、コンディショニング処理の効果によ り, 可視波長域において損失の増加が抑えられており, ファイバを長尺化する際, 有効である.

$\mathrm{AFM}$ (Atomic Force Microscope)により，製作した $\mathrm{Ag} /$ Buffer/SUS中空ファイバの銀膜の表面を観察した。AFM で測定した微小面積での平面凹凸の平均值からのずれの 二乗平均值を内面粗さとすれば，ステンレスチューブの 内面粗さの $0.3 \sim 0.9 \mu \mathrm{m}$ から, 本手法で $88 \sim 142 \mathrm{~nm}$ と $1 / 2$ 〜 $1 / 10$ 程度減少した。

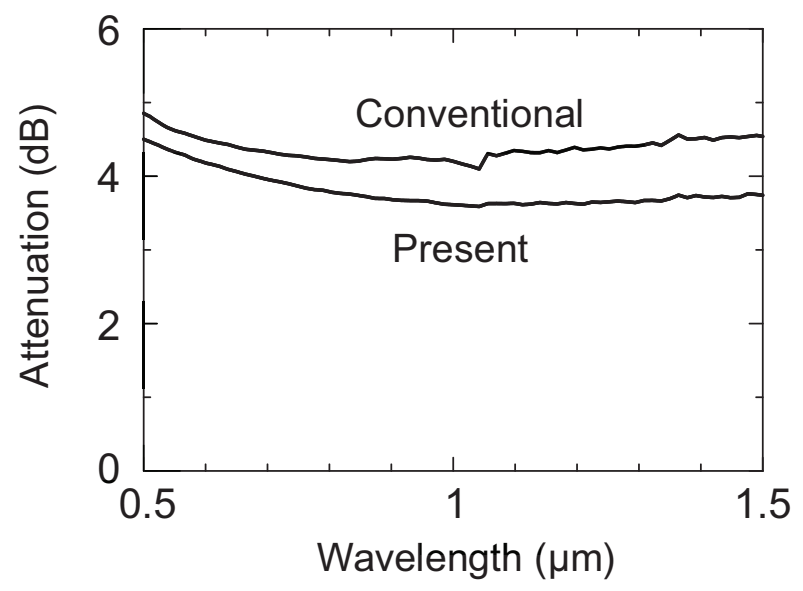

Fig. 5 Measured loss spectra of Ag/Buffer/SUS hollow fibers $(550 \mu \mathrm{m} \phi \times 20 \mathrm{~cm})$ fabricated by using Acrylic-silicon solution with coating times of 4 times. The fibers are excited by the Gaussian beam with a full-width at half-maximum of $10.6^{\circ}$.

\section{3. 銀中空ステンレスファイバの特性}

中空ステンレス短尺ファイバの成果を基に，シリコン アクリル樹脂膜 (内装平滑化用) 内装中空ステンレスファ イバの長尺化を行う。 Fig. 6に2本のAg/Buffer/SUS中空 ファイバの可視波長域における損失波長特性を示す. Ag膜の成膜は安定に行われ，製作されたAg/Buffer/SUS 中空ファイバの損失值は, $\mathrm{Ag} / \mathrm{SUS}$ 中空ファイバより低 損失になることが分った４回の重ね塗りにより損失の 増加が抑えられている。可視パイロットビームとして考 えているレーザーダイオード光の発振波長 $650 \mathrm{~nm}$ 付近 では，スペクトル上で損失が最大 $6 \mathrm{~dB}$ 程度低減してい る。本稿の中空ファイバの主な目的は赤外伝送であり, Fig. 7にAg/Buffer/SUS中空ファイバの赤外損失スペクト ルを示す. $\mathrm{CO}_{2}$ レーザーの波長10.6 $\mu \mathrm{m}$ では, $\mathrm{Ag} / \mathrm{SUS} の$ 損失值と同程度になることが分った。 Er:YAGレーザー

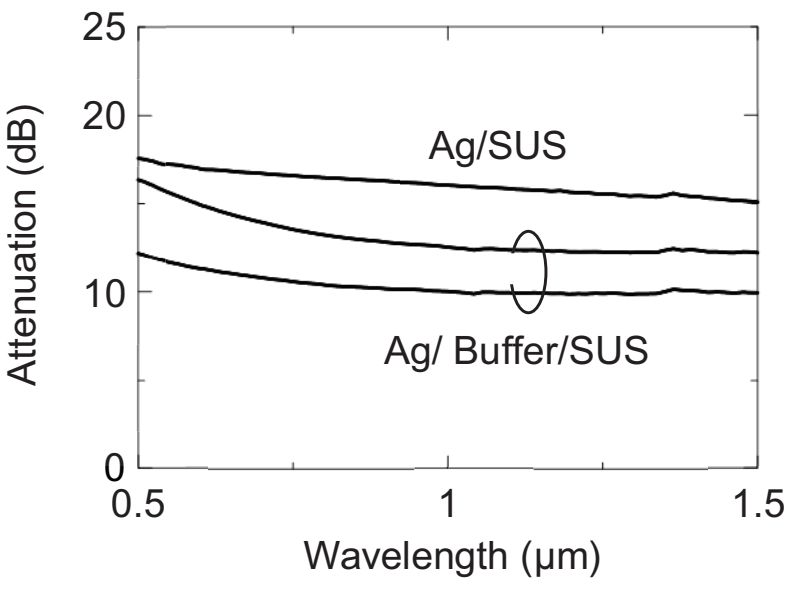

Fig. 6 Measured loss spectra of Ag/Buffer/SUS hollow fibers. The length and inner diameter of fiber are $1 \mathrm{~m}$ and $550 \mu \mathrm{m}$, respectively. The fibers are excited by the Gaussian beam with a full-width at half-maximum of $10.6^{\circ}$.

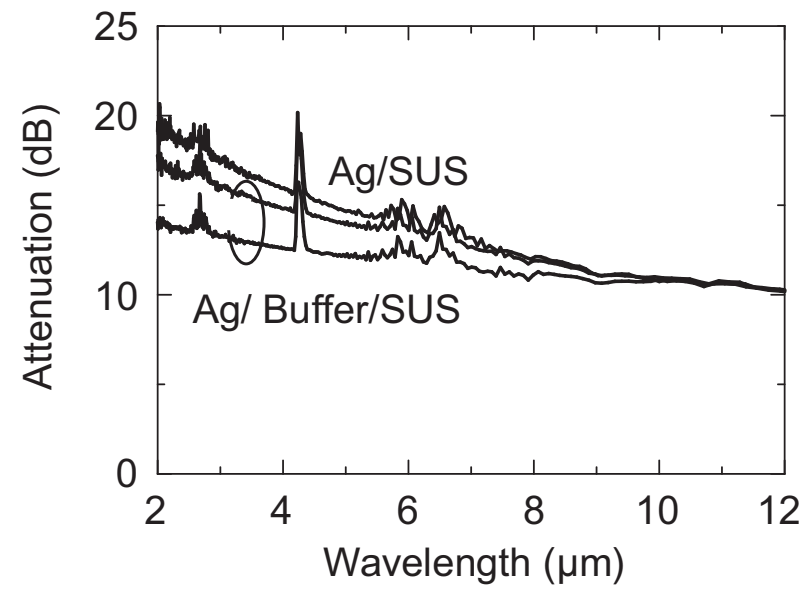

Fig. 7 Measured loss spectra of Ag/Buffer/SUS hollow fibers. The length and inner diameter of fiber are $1 \mathrm{~m}$ and $550 \mu \mathrm{m}$, respectively. The fibers are excited by the Gaussian beam with a full-width at half-maximum of $12^{\circ}$. 
Er:YAG laser $(\lambda=2.94 \mu \mathrm{m})$

$\operatorname{LD}(\lambda=650 \mathrm{~nm})$

Hollow fiber $(550 \mu \mathrm{m} \phi \times 1 \mathrm{~m})$

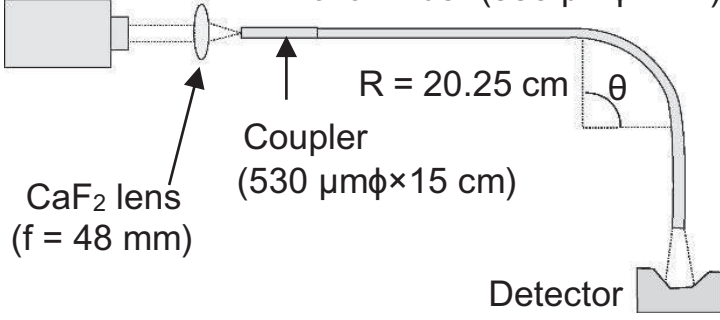

Fig. 8 Loss measurement of hollow fiber for Er: YAG laser light $(\lambda=2.94 \mu \mathrm{m})$ and laser diode $(\lambda=650 \mathrm{~nm})$.

の波長 $2.94 \mu \mathrm{m}$ で損失は明らかに小さくなっている. Fig. 7 の結果から, 本手法は, 波長 $8 \mu \mathrm{m}$ ま゙の赤外伝送路と して有効であることが分った。

次に, 波長2.94 $\mu \mathrm{m}$ の Er:YAGレーザーと波長 $650 \mathrm{~nm}$ の レーザーダイオード (LD)を用い, 銀中空ステンレス ファイバの伝送特性を評価した。測定系をFig. 8に示 す. 内径 $530 \mu \mathrm{m}$, 長さ $15 \mathrm{~cm}$ の銀中空ファイバを結合 ファイバとし, Er:YAGレーザーとLDからの光を内径 $550 \mu \mathrm{m}$, 外径780 $\mu \mathrm{m}$, 長さ $1 \mathrm{~m}$ の銀中空ステンレスファ イバに入射する。銀中空ステンレスファイバの出力端を 曲げ半径 $20.25 \mathrm{~cm}$ で曲げ，損失評価を行った。測定結果 をFig. 9に示す. LD光の伝送損失は, Ag/SUS中空ファイ バに比べ, Ag/Buffer/SUS中空ファイバの損失は, 直線 状態で $2 \mathrm{~dB}$ 程度低減し, 大きな角度で曲げた場合には, 更に大きく低減していることが分る。これは，ステンレ スチューブの内面粗さを大幅に低減することができた ためである。また，Er:YAGレーザー光の伝送損失は， $\mathrm{Ag} / \mathrm{Buffer} / \mathrm{SUS}$ 中空ファイバの場合, 直線状態で約 $6 \mathrm{~dB}$, 出射端を曲げ半径 $20.25 \mathrm{~cm}$ で180度曲げた状態で, $14 \mathrm{~dB}$ 程度であり, Ag/SUS中空ファイバの損失值が, 直線で $9 \mathrm{~dB} ， 180$ 度曲げで $23 \mathrm{~dB}$ であることを比較すると大きく 低減している。 なお， 中空ステンレスファイバへの入射 エネルギーは, $40 \mathrm{~mJ} /$ pulse, 繰り返し周波数は, $10 \mathrm{~Hz}$,

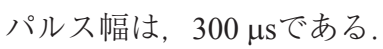

\section{4. まとめ}

ステンレスチューブの内面粗さを低減する手法につい て検討を行った。 シリコンアクリル樹脂膜を内面平滑化 膜として使用することにより，内面粗さを大幅に低減し た銀膜を形成することに成功した。その結果，可視パイ

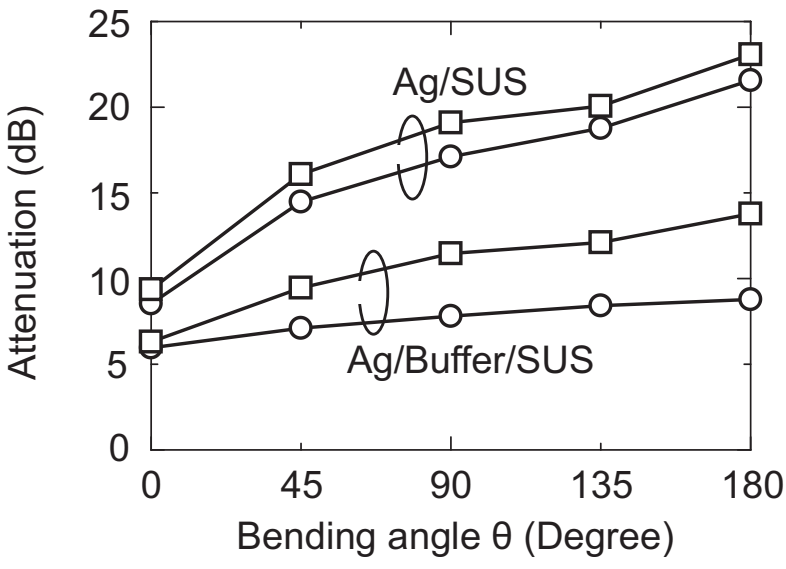

Fig. 9 Bending losses of Ag/Buffer/SUS hollow fiber (550 $\mu \mathrm{m} \phi \times 1 \mathrm{~m})$ for Er: YAG laser light $(\lambda=2.94 \mu \mathrm{m})$ and laser diode $(\lambda=650 \mathrm{~nm})$. A bending radius of $20.25 \mathrm{~cm}$. Circular $(\bigcirc)$ and square $(\square)$ plots correspond to laser with a wavelength of $650 \mathrm{~nm}$ and $2.94 \mu \mathrm{m}$, respectively.

ロット光を高効率で伝送できる銀中空ステンレスファイ バを実現した。

\section{参考文献}

1) Y. Matsuura, A. Hongo, and M. Miyagi: Appl. Opt. 29 (1990) 2213.

2) I. Gannot, S. Schrunder, J. Dror, A. Inberg, T. Ertl, J. Tschepe, G. J. Muller, and N. Groitoru: IEEE Trans. Biomed. Eng. 42 (1995) 967.

3) J. A. Harrington: Milestone Series MS-9 (SPIE, Bellingham, WA, 1990).

4) J. E. Melzer and J. A. Harrington: Proc. SPIE 9317 (2015) 93170H-1.

5) Y. W. Shi, Y. Wang, Y. Abe, Y. Matsuura, M. Miyagi, S. Sato, M. Taniwaki, and H. Uyama: Appl. Opt. 37 (1998) 7758.

6) 阿部由起雄, 岩井克全, 豊岡理人, 片桐 崇史, 金森 亮平, 石 芸尉, 松浦 裕司, 宮城光信, 大石純子, 岡上吉秀: レーザー研究 30 (2002) 472.

7) C. D. Rabii and J. A. Harrington: Opt. Eng. 38 (1999) 1490.

8) Y. W. Shi, Z. Y. Pan, Y. Matsuura, and M. Miyagi: Opt. Laser Technol. 32 (2000) 273.

9) 岩井克全, 阿部 由起雄, 石 芸尉, 松浦 裕司, 宮城光信, 大石 純子，岡上吉秀：レーザー研究 30 (2002) 255.

10) K. Iwai, H. Takaku, M. Miyagi, Y. W. Shi, and Y. Matsuura : Proc. SPIE 9317 (2015) 93170I-1.

11) S. Ouyang, Y. W. Shi, Y. Matsuura, and M. Miyagi: Opt. Laser Technol. 35 (2003) 65.

12) M. Miyagi and S. Kawakami: J. Lightwave Technol. LT-2 (1984) 116. 